\title{
Effect of techniques, trays and materials on accuracy of impressions clinically made
}

\author{
Efeito de técnicas, moldeiras e materiais na exatidão de moldagens \\ odontológicas.
}

\author{
Aion Mangino MESSIAS ${ }^{a}$ (D), Stephania Caroline Rodolfo SILVA ${ }^{a}{ }^{(1)}$, Filipe de Oliveira ABI-RACHED ${ }^{b}$ (), \\ Raphael Freitas SOUZA ${ }^{c}$ (i), José Maurício dos Santos Nunes REIS ${ }^{a *}(\mathbb{1})$ \\ aUNESP - Universidade Estadual Paulista, Faculdade de Odontologia de Araraquara, Departamento de Materiais \\ Odontológicos e Prótese, Araraquara, SP, Brasil \\ 'UNIARA - Universidade de Araraquara, Araraquara, SP, Brasil \\ 'McGill University, Faculty of Dentistry, Division of Oral Health and Society, Montreal, Quebec, Canada
}

How to cite: Messias AM, Silva SCR, Abi-Rached FO, Souza RF, Reis JMSN. Effect of techniques, trays and materials on accuracy of impressions clinically made. Rev Odontol UNESP. 2019;48:e20190064. https://doi.org/10.1590/18072577.06419

\begin{abstract}
Resumo
Introdução: Realizar moldagens precisas e dimensionalmente estáveis que dupliquem a condição oral é um passo essencial para a confecção de restaurações indiretas de qualidade, garantindo seu sucesso e longevidade. Diversos estudos tem demonstrado os prós e contras de diferentes técnicas de moldagem, mas nenhum consenso da melhor técnica ainda foi descrito. Objetivo: Este estudo avaliou a exatidão de modelos de gesso confeccionados por diferentes técnicas de moldagem, moldeiras e materiais. Material e método: 10 pacientes foram selecionados e 20 moldes dos dentes \#13 até \#16 foram realizados utilizando técnicas simultânea (SS) e de dois passos, realizados com moldeiras parciais metálicas e individuais de resina acrílica, silicones de adição e condensação. Gesso tipo IV foi usados para os vazamentos. Três fotografias de cada paciente (baseline), assim como dos seus respectivos modelos de gesso foram realizadas e sua área foi então mensurada, na porção vestibular. Comparações de valores de área entre os grupos experimentais e o baseline foram performadas. Os dados mostraram aderência a curva normal, sendo submetidos ao teste 3-way ANOVA/Bonferroni $(\alpha=.05)$. Resultado: As técnicas produziram diferenças significativas $(\mathrm{P}=0.02)$.Técnica simultânea foi mais precisa que a $\mathrm{BUR}(\mathrm{P}=0.0003$; $95=1,22$ a 5.98$)$, mas ambas resultaram em modelos similares àqueles feitos por meio das técnicas de PVC, MOV e sem NR, que foram similares entre si $(P>0.05)$. Conclusão: Técnica simultânea demonstrou valores absolutos similares àqueles demonstrados pelo baseline.
\end{abstract}

Descritores: Materiais para moldagem odontológica; elastômeros de silicone; técnica de moldagem odontológica; medidas, métodos e teorias.

\begin{abstract}
Introduction: Making accurate and dimensionally stable impressions to duplicate oral conditions and tooth morphology is an essential step of prosthetic dentistry for fabricating well-fitted indirect restorations and, consequently, ensure the longevity and success of the treatment. Several authors describe pros and cons of different impression techniques, although there is no unanimity among them about the best one. Objective: This study evaluated casts' accuracy made by different impression techniques, trays and materials. Material and method: 10 patients were selected and 20 impressions from teeth \#13 to \#16 were performed using single-step (SS) and two-step techniques, made with metal stock and customized acrylic resin partial trays, vinyl polysiloxane and condensation silicone rubbers. Type IV gypsum was used to pour the casts. Three photographs of each patient (baseline), as their respective gypsum casts, were taken, measured in their interested buccal surface area. Comparisons of area values among experimental groups and baseline were performed. Data showed adherence to normal curve, being submitted to 3-way ANOVA/Bonferroni test $(\alpha=.05)$. Result: Technique produced significant
\end{abstract}


differences $(P=0.02)$. SS technique was more accurate than BUR one $(P=0.003 ; 95=1.22$ to 5.98$)$, but both resulted in similar casts to PVC, MOV and NR techniques, which were similar to each other $(P>0.05)$. Conclusion: SS technique showed the closest absolute values to baseline.

Descriptors: Dental impression materials; silicone elastomers; dental impression technique; measurements, methods and theories.

\section{INTRODUCTION}

Despite the evolution of digital impression and cast fabrication methods, their accuracy and reproducibility not necessarily means the replacement of clinical-lab conventional procedures ${ }^{1}$. Making accurate and dimensionally stable impressions to duplicate oral conditions and tooth morphology is an essential step of prosthetic dentistry for fabricating well-fitted indirect restorations ${ }^{2}$ and, consequently, ensure the longevity and success of the treatment ${ }^{3}$. There are reports 4,5 concerning how to improve the accuracy of impression techniques, including control of the room temperature, use of single or two-step techniques and of metal or customized acrylic resin trays. Moreover, impression accuracy is influenced by the oral conditions (periodontal health and finish line position) and, finally, by the impression materials' properties ${ }^{4-6}$.

Several elastic impression materials are available for dental use: hydrocolloids and synthetic elastomeric materials, including polysulfide, condensation silicone, vinyl polysiloxane (VPS) and polyether ${ }^{4,6-8}$. The implementation of putty-wash condensation silicones was a landmark advance among the impression materials, since it not requires customized trays ${ }^{9}$. Moreover, it presents accurate surface details reproduction and adequate working time, besides low cost, being daily admitted on clinical works, especially in many western countries. In turn, VPS materials present excellent physical and chemical properties ${ }^{10}$, such as high tear resistance and dimensional stability and low permanent deformation ${ }^{5,6}$.

Regarding accuracy and dimensional stability, the elastomeric materials have been better than hydrocolloids ${ }^{11}$. With respect to condensation silicones, the average pouring time is about 30 minutes, while new formulations entitled as premium C-silicone (e.g. Speedex; Coltène) allow, according to its manufacturer, a pouring time up to 7 days as a result of low shrinkage and high dimensional stability like as A-quality silicones.

Furthermore, while literature tends to demonstrate that the optimum accuracy is obtained with customized trays ${ }^{12}$, some authors ${ }^{13}$ showed that trays did not affect the accuracy of casts. Thus, the use of stock trays for elastomeric impressions is popular in general practice due to its easy handling and performance ${ }^{14}$.

Several authors describe pros and cons of different impression techniques,3,15-18, although there is no unanimity among them about the best one. In addition, to the best authors' knowledge there are no studies comparing the results of VPS with those of premium C-silicones. Thus, the null hypotheses of this study were that there was no difference among techniques (1), trays (2) and materials (3) on accuracy of impressions clinically made by means of area measurements.

\section{MATERIAL AND METHOD}

This study protocol was approved by the Ethics Committee of the Araraquara Dental School, São Paulo State University - UNESP (application \#75/11). Ten patients were enrolled following the inclusion and exclusion criteria listed in Table 1. 
Table 1. Inclusion and exclusion criteria for patients' recruitment

\begin{tabular}{ll}
\hline Inclusion Criteria & Exclusion Criteria \\
\hline Age between 18-80 years & Pregnancy \\
Absence of caries and/or periodontal disease in the & Allergic reaction known and informed to any material used \\
maxillary right quadrant & - \\
Teeth of the right maxillary quadrant healthy or with Periodontal disease or teeth impaired by caries / trauma / \\
satisfactory direct restorations & unsatisfactory restorations \\
& Use of orthodontic braces \\
& Concurrent or recent participation in another clinical \\
& study \\
\hline
\end{tabular}

For each patient, 20 partial impressions from teeth \#13 to \#16 were obtained by single-step (SS) or two-step techniques. For two-step ones, the relief for the wash material was obtained with polyvinyl chloride film (PVC); slow-speed tungsten carbide bur (Maxicut no. 1520; Edenta AG, AU, Switzerland) and scalpel blade no. 15C (Swann Morton Ltd., Sheffield, United Kingdom) (BUR); and tray small movements (MOV). No relief (NR) was used as negative control. For the PVC technique, a PVC film was used to recover the putty-body material and it was removed after impression has been taken from the oral cavity. For the BUR technique, the axial region of each tooth was worn by Maxicut bur, and the interpapillary region removed with scalpel blade in the putty-body impression material. For the MOV technique, after the putty-body material was inserted in the oral cavity, small movements were made in the tray during 5.0 seconds. For all two-step techniques, the putty-body material was relined with the light-body one.

\section{Tray's Preparation}

The impressions were made with aluminum stock and acrylic resin customized partial trays. To make the customized trays, one week previously of the impressions, a total maxillary arch impression of each patient was obtained with condensation silicone (Speedex; Coltène/Whaledent Inc., Ohio, USA) by single-step technique. The impressions were poured with type IV stone (GC Fuji Rock EP; GC Europe, Leuven, Belgium), respecting the water/powder ratio recommended by the manufacturer. One coat of sodium alginate (Cel-Lac; SSWhite, St. Petersburg, Florida, USA) was applied to the stone surfaces and a relief with 2 wax sheets (Wilson; Polidental Indústria e Comércio Ltd., Cotia, São Paulo, Brazil) was made over the interested region of the gypsum casts (Figures $1 \mathrm{~A}$ and B). The acrylic resin (Vipi Flash; Vipi Industry, Pirassununga, São Paulo, Brazil) was manipulated according to the manufacturer's recommendations and in dough stage it was packed and pressed between glasses slides mounted with $3.0 \mathrm{~mm}$ spacers to enforce standardized thickness. After polymerization, the wax relief was removed and the trays were perforated and adjusted in borders.

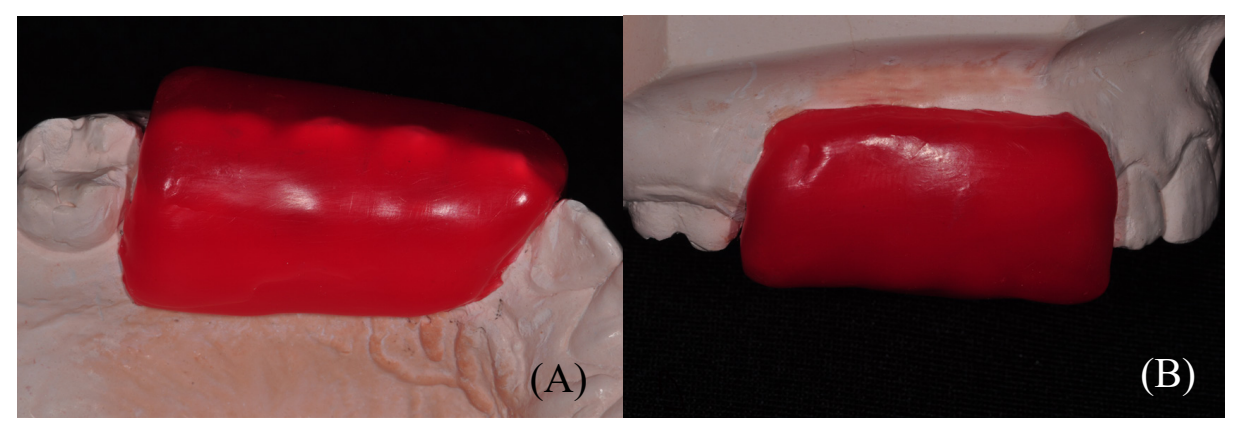

Figure 1. (A) Occlusal view of the relief obtained with 2 wax sheets over the interested region. (B) Lateral view of the relief obtained with wax. 
To standardize the thickness of impression materials, passive seating and pressure of trays, a $2.0 \mathrm{~mm}$ spacer was positioned over the occlusal surface of the casts. Then, the trays were placed over the spacer and extensions in autopolymerizing acrylic resin (Pattern Resin LS, GC America Inc., Alsip, Illinois, USA) were made on teeth \#12 and \#17 (Figures $2 \mathrm{~A}$ and B).

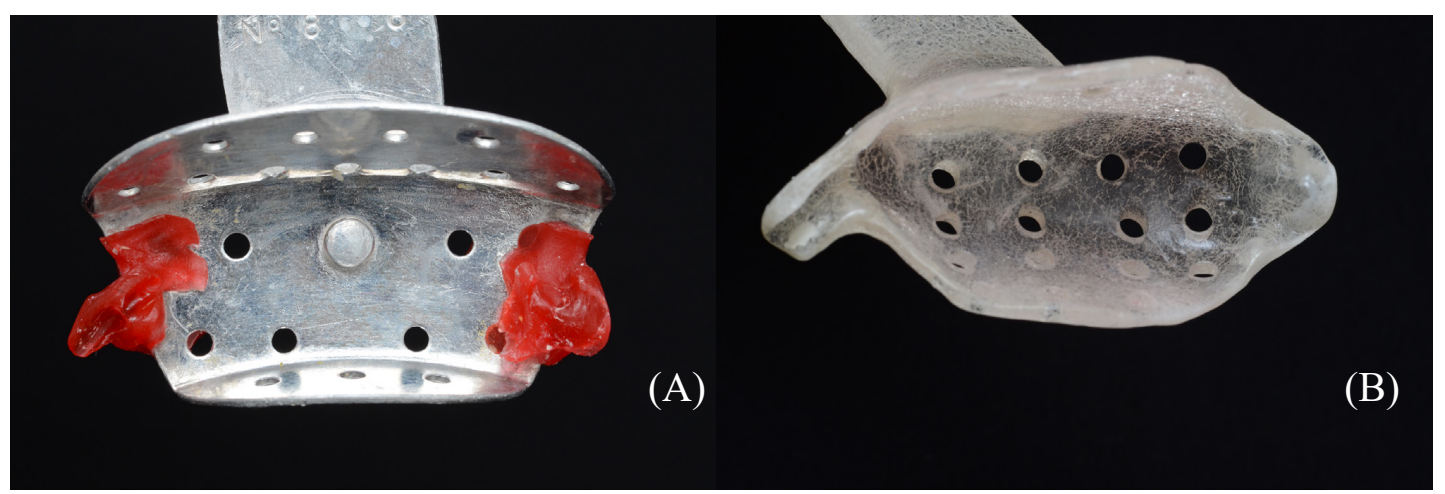

Figure 2. (A) Metal stock customized partial tray with extensions in autopolymerizing acrylic resin (Pattern

Resin LS, GC America, Inc.) made on teeth \#12 and \#17. (B) Acrylic resin customized partial tray with extensions in autopolymerizing acrylic resin (Pattern Resin LS, GC America, Inc.) made on teeth \#12 and \#17.

\section{Impression Materials}

The impression materials used in this study were a condensation silicone (Speedex; Coltène/Whaledent Inc., Ohio, USA) and a vinyl polysiloxane (VPS) material (Express XT; 3M ESPE, St. Paul, Minnesota, USA). All mixing procedures followed the manufacturers' instructions. A metal spatula was used for mixing the light-body condensation silicone over a glass plate, while the putty material was mixed by hand. For the light-body VPS material, a mixing tip was used in the manufacturer's dispenser. The initial portion $(2.0 \mathrm{~cm})$ of the mixture was discarded, ensuring its homogeneity. Due to the incompatibility of VPS material with latex, the putty silicone was mixed by hand with vinyl gloves ${ }^{19}$.

\section{Impressions and Casts}

A single calibrated operator performed the impressions in a sequence established by a random (as recommended by the CONSORT Statement) and blind raffle. For each patient, one impression per day was done until all techniques were performed (Figure 3). All impressions were evaluated for retention in the tray and absence of bubbles and/or voids. The impression were washed in tap water for 10 seconds, and sprayed with $0.5 \%$ sodium hypochlorite. After 10 minutes, the impressions were rinsed again in tap water for 10 seconds. After 20 and 110 minutes, the condensation silicone and VPS impressions were poured, respectively. Type IV stone (GC Fuji Rock EP; GC Europe, Leuven, Belgium) was vacuum mixed (Turbo Mix; EDG Equipment and Controls Ltd., São Carlos, São Paulo, Brazil), following the manufacturer's recommendations, and poured into the impression under vibration. After 40 minutes, the gypsum casts were removed from the molds and the presence of bubbles and/or tear was verified. 


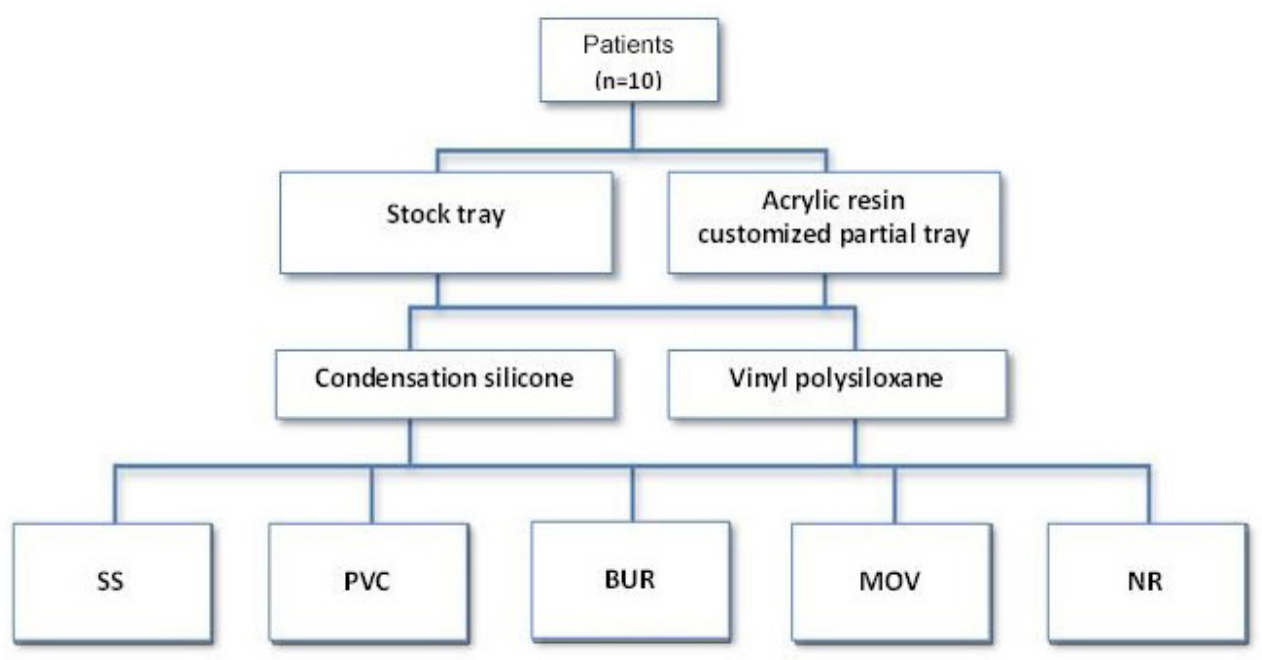

Figure 3. Representative chart of the experimental conditions.

\section{Image Acquisition and Area Measurement}

For each patient, three photographs (RAW extension, $300 \mathrm{dpi}$ ) of the interested region (teeth \#13 to \#16) were obtained in right lateral view with a Nikon D7000 digital camera (Nikon Corporation, Minato, Tokyo, Japan) and a macro lens (AF-S VR Micro-Nikkor 105 mm f/2.8G IF-ED; Nikon Corporation, Minato, Tokyo, Japan) coupled to a circular flash (Sigma EM-140 DG; Sigma Corporation, Kawasaki, Kanagawa, Japan). Using a camera tripod and a customized radiographic positioner coupled to the camera lens (Figure 4), the angle, focal length and framing of photographs were standardized. Radiographic positioners were customized with an occlusal registration in acrylic resin (Pattern Resin LS; GC America, Inc., Alsip, Illinois, USA). Photographs were taken in the presence of a digital caliper $( \pm 0.01 \mathrm{~mm}$; Mitutoyo Sul Americana Ltd., Suzano, São Paulo, Brazil) for calibration of the Image J software (version 1.45s) used for image analysis. For this purpose, the ends of the caliper were fixed with opening of $1.0 \mathrm{~mm}$. Images were imported into Image $\mathrm{J}$ and a calibration was performed with a software tool ("set scale") that determine how much an object of known size has in pixels on the images ${ }^{9}$. Thus, informing how much $1.0 \mathrm{~mm}$ corresponds to pixels in each image, it was possible to calculate the total area $\left(\mathrm{mm}^{2}\right)$ of the buccal surface of the teeth by their perimeter contour.

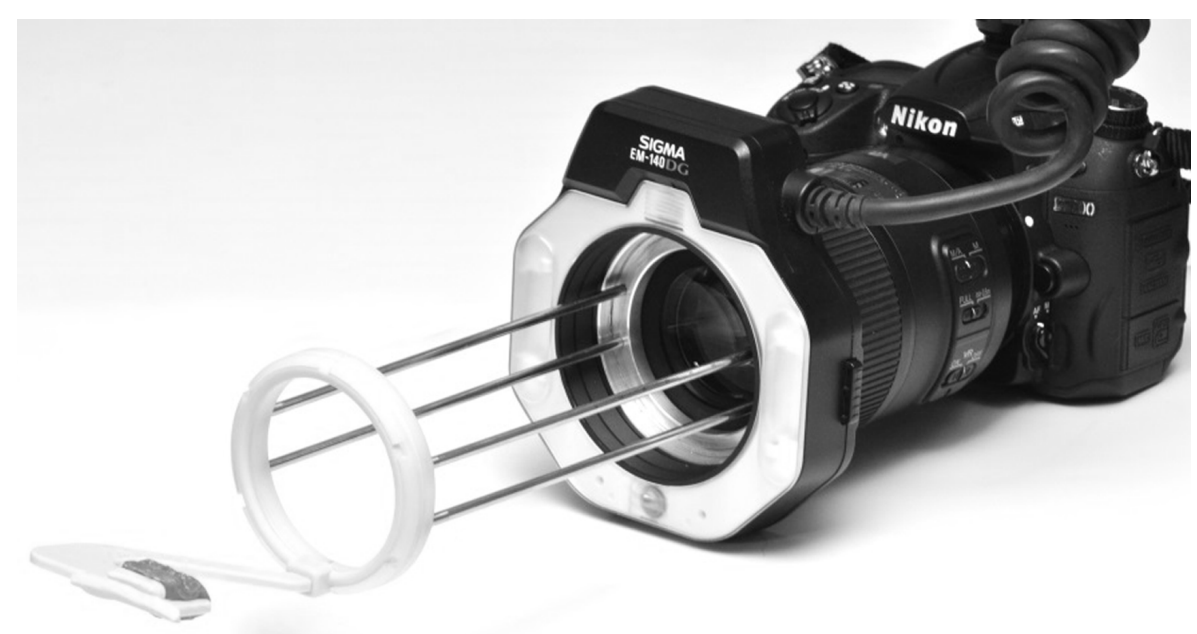

Figure 4. Radiographic positioner (with occlusal registration) attached to the camera lens. 
Aiming to evaluate the standardization of the readings, three clinical photographs of each patient were taken. The total area of interest of each image was measured and the means and standard deviations were obtained. Thus, the coefficient of variance was calculated and should present a maximum value of $4.0 \%$, ensuring the reliability of the measurements as Baseline values. After obtaining all impressions and casts, the same procedures were clinically performed again for each patient, verifying the absence of changes in gingival margins compared to their initial condition, which would influence the results. The area measurements from clinical photographs were respectively compared with those obtained from gypsum casts images. For obtaining the casts images, the same standardizing procedures were performed. After edition, images were imported into Image $J$ and the area was measured in triplicate ${ }^{9}$ by two blind and calibrated examiners. The mean area of each cast was compared with baseline. The difference between baseline values and those from the respective casts were expressed in $\mathrm{mm}^{2}$. Other authors have used this comparative method to analyze gypsum casts ${ }^{2}$. For statistical analysis, irrespective of the patient, the results of each technique were grouped to compare the effect of the factors technique, tray and material on the dimensions of the casts.

\section{Statistical Analysis}

Statistical methods were used to evaluate the influence of the independent variables (technique, tray, material and their interactions) on the accuracy of gypsum casts. The software IBM SPSS Statistics version 20.0 (IBM Corporation; Armonk, New York, USA) was used, adopting a $95 \%$ confidence interval.

The area $\left(\mathrm{mm}^{2}\right)$ measured in each cast was subtracted from the respective baseline value. Positive values represent higher mean area of the baseline in relation to the casts, while negative values represent higher mean area of the gypsum cast in relation to baseline.

Data were evaluated for normality (Shapiro-Wilk) to investigate the sample distribution, followed by Sphericity Mauchly's analysis and repeated measures 3-way ANOVA. When the Sphericity rule (Mauchly's test) was violated, Greenhouse-Geisser correction was applied. Paired comparisons were performed by Bonferroni test $(\alpha=.05)$.

\section{RESULT}

Sphericity Mauchly's analysis indicated that only the factor technique showed statistically significant effect $(P=.02)$, with Epsilon value of .56 for Greenhouse-Geisser correction. From Table 2 it can be seen that SS technique presented higher accuracy than BUR one $(P=.003$; $95=1.22$ to 5.98). There was no significant difference among PVC, MOV, NR and SS techniques $(P \geq .05)$. PVC, MOV and NR techniques were similar to each other and to the BUR one $(P \geq .05)$. The SS technique produced casts with absolute area mean value $\left(173.13 \mathrm{~mm}^{2}\right)$ closer to that clinically measured (baseline; perimeter area $=172.48 \mathrm{~mm}^{2}$ ).

Table 2. Difference mean area values $\left(\mathrm{mm}^{2}\right)$ and standard deviations $( \pm)$ between baseline and gypsum casts for each impression techniques after Bonferroni correction

\begin{tabular}{ccccc}
\hline \multicolumn{5}{c}{ Impression Techniques } \\
\hline \multirow{2}{*}{ Single-Step (SS) } & PVC film (PVC) & $\begin{array}{c}\text { Maxicut bur/Scalpel } \\
\text { Blade (BUR) }\end{array}$ & Small Movements (MOV) & No relief (NR) \\
\hline$-0.648( \pm 2.128)$ & $-3.671( \pm 2.240)$ & $-4.244( \pm 2.150)$ & $-2.579( \pm 2.152)$ & $-3.029( \pm 1.891)$ \\
$\mathrm{A}$ & $\mathrm{AB}$ & $\mathrm{B}$ & $\mathrm{AB}$ & $\mathrm{AB}$ \\
\hline
\end{tabular}

Mean values followed by the same capital letter are statistically similar $(P \geq .05)$. 


\section{DISCUSSION}

The present study evaluated the accuracy of casts made by different one-/two-step impression techniques, trays and materials. In this investigation, impressions were clinically made and not using standardized stainless steel models like as commonly proposed by other authors ${ }^{14,20,21}$. In these in vitro studies, the absence of saliva plays an important role as wetting of impression material depends on the surface energy of an impressed surface. Metal models are non-absorbent to liquids unlike the oral tissues. In addition, most of in vitro investigations simulate full crown prepared abutments without the presence of adjacent teeth. Thus, the absence of undercuts regions does not represent a real condition and may influence the results obtained from different impression techniques. Based on the results, the null hypotheses regarding the effect of trays and materials on the gypsum casts accuracy were accepted, while the effect of techniques did not support our first null hypothesis.

The dimensional stability of an elastomeric impression is influenced by the polymerization shrinkage of the material, chemical reactions' sub products, thermal changes and elastic recovery ${ }^{8}$, while factors such as disinfecting, pouring time and impression technique may also influence its accuracy8,16,17. According to its manufacturer, Speedex premium C-silicone has elastic recoverability and reproduction, which is usually achieved by VPS materials. In addition, due to low shrinkage, they suggest that impressions stay dimensionally stable for up to 7 days. These properties may help to explain the outstanding performance presented by this condensation silicone; comparable to the Express XT VPS material. Additionally, Garrofé et al. ${ }^{22}$ observed that Speedex had comparable linear dimensional stability to some VPS materials over time. These facts provide scientific evidence to support their use in clinical routine, especially in many western countries. On the other hand, other properties such as reproduction details, elastic recovery and tear strength should be evaluated to ensure the quality of impressions and pourings over time; especially in cases of double pouring.

Unlike trays and impression materials, the impression techniques were decisive on the accuracy of gypsum casts. Corroborating the findings of Basapogu et al. ${ }^{23}$, accurate casts were obtained with either metal stock trays or acrylic resin custom trays. Although custom trays allow the obtaining of outstanding accuracy in impressions procedures, the use of metal stock trays is popular and well accepted in general practice. Other studies ${ }^{24,25}$ showed no significant effect regarding the influence of tray material on the dimensional stability of impressions and poured casts. Despite this, the use of custom trays might be more predictable and economical because less material is necessary for the impression procedures 25 .

Regarding the impression techniques, there was a significant difference between the SS and BUR techniques, which showed the closest and the farthest values to baseline, respectively. No differences were observed when the other two-step and the SS techniques were compared. Similar results were recently observed by Silva et al.20, who observed that 1 -step technique did not differ from three two-step techniques, despite single-step had produced closer results to master model. The similarity between baseline values and those obtained with the SS technique is probably related to the thin layer of the low viscosity material, which remained deposited in specific and critical areas to be impressed. The viscosity of impression silicones is influenced by the filler content in its chemical composition ${ }^{10}$. According to Mandikos ${ }^{7}$, materials with lower viscosity show higher dimensional change, due to its lower filler content. Similarly, Fano et al. ${ }^{11}$ reported that as higher as the viscosity, smaller the dimensional change of a silicone impression material. Thus, regarding dimensional stability of impressions, the results of this study corroborate the findings of Mandikos ${ }^{7}$ and Fano et al. ${ }^{11 .}$

On the other hand, a higher volume of filler content means that there is less elasticity and fluidity, resulting in lower precision ${ }^{2}$. Thus, it is always necessary to use small thickness of lower viscosity materials with putty/heavy-body ones, achieving accurate impressions, with minimal distortion and high dimensional stability. Comparing SS and BUR techniques, the results of the 
present study partially corroborate the study by Hung et al. ${ }^{15}$, which compared the accuracy of one- and two-step impression techniques with VPS material and found that the one-step technique was more accurate.

The BUR technique resulted in area mean values more distant from baseline values. A reasonable explanation for this fact would be the difficulty to standardize the amount of relief all over the interest area, standardizing only the time of putty-body silicone wears. In addition, it was not possible to standardize the pressure and the removal amount of putty-body material. This may have given an uneven light-body material content in certain regions, contributing to more heterogeneous deformations compared to the other techniques 6 . Furthermore, as inherent disadvantages of the BUR technique can be considered: 1) high dirt, since large amount of waste is resultant from the wear of the putty-body material prior to insertion of the light-body one; and 2) the relatively longer time spent for its performance compared to the other techniques, requiring greater clinical time.

Although several impression techniques, trays and materials are routinely used in clinical practice, future studies evaluating digital impression techniques and marginal adaptation of frameworks obtained from such conventional techniques is needed to verify their clinical performance and optimize the clinical time.

\section{CONCLUSIONS}

Based on the proposed methodology and obtained results, it may be concluded that:

$\checkmark \quad$ Impression technique was the decisive factor on the accuracy of gypsum casts;

$\checkmark \quad$ The different trays and impression materials did not influence the accuracy of gypsum casts;

$\checkmark \quad$ SS technique showed the closest absolute values to baseline, while two-step techniques seems to be not essential.

\section{ACKNOWLEDGEMENTS}

This research was supported by the "Fundação de Amparo à Pesquisa do Estado de São Paulo - FAPESP” (grants \# 2011/19314-0 and \#2011/19165-4).

\section{REFERENCES}

1. Cho SH, Schaefer O, Thompson GA, Guentsch A. Comparison of accuracy and reproducibility of casts made by digital and conventional methods. J Prosthet Dent. 2015 Apr;113(4):310-5. http://dx.doi.org/10.1016/j.prosdent.2014.09.027. PMid:25682531.

2. Chen SY, Liang WM, Chen FN. Factors affecting the accuracy of elastometric impression materials. J Dent. 2004 Nov;32(8):603-9. http://dx.doi.org/10.1016/j.jdent.2004.04.002. PMid:15476954.

3. Kang AH, Johnson GH, Lepe X, Wataha JC. Accuracy of a reformulated fast-set vinyl polysiloxane impression material using dual-arch trays. J Prosthet Dent. 2009 May;101(5):332-41. http://dx.doi.org/10.1016/S0022-3913(09)60066-4. PMid:19410067.

4. Endo T, Finger WJ. Dimensional accuracy of a new polyether impression material. Quintessence Int. 2006 Jan;37(1):47-51. PMid:16429703. 
5. Balkenhol M, Haunschild S, Erbe C, Wöstmann B. Influence of prolonged setting time on permanent deformation of elastomeric impression materials. J Prosthet Dent. 2010 May;103(5):288-94. http://dx.doi.org/10.1016/S0022-3913(10)60060-1. PMid:20416412.

6. Lu H, Nguyen B, Powers JM. Mechanical properties of 3 hydrophilic addition silicone and polyether elastomeric impression materials. J Prosthet Dent. 2004 Aug;92(2):151-4. http://dx.doi.org/10.1016/j.prosdent.2004.05.016. PMid:15295324.

7. Mandikos MN. Polyvinyl siloxane impression materials: an update on clinical use. Aust Dent J. 1998 Dec;43(6):428-34. http://dx.doi.org/10.1111/j.1834-7819.1998.tb00204.x. PMid:9973714.

8. Craig RG. Review of dental impression materials. Adv Dent Res. 1988 Aug;2(1):51-64. http://dx.doi.org/10.1177/08959374880020012001. PMid:3073785.

9. Faria AC, Rodrigues RC, Macedo AP, Mattos MG, Ribeiro RF. Accuracy of stone casts obtained by different impression materials. Braz Oral Res. 2008 Oct-Dec;22(4):293-8. http://dx.doi.org/10.1590/S1806-83242008000400002. PMid:19148382.

10. Herfort TW, Gerberich WW, Macosko CW, Goodkind RJ. Viscosity of elastomeric impression materials. J Prosthet Dent. 1977 0ct;38(4):396-404. http://dx.doi.org/10.1016/0022-3913(77)90093-2. PMid:269278.

11. Fano V, Gennari PU, Ortalli I. Dimensional stability of silicone-based impression materials. Dent Mater. 1992 Mar;8(2):105-9. http://dx.doi.org/10.1016/0109-5641(92)90064-J. PMid:1521690.

12. Burns J, Palmer R, Howe L, Wilson R. Accuracy of open tray implant impressions: An in vitro comparison of stock versus custom trays. J Prosthet Dent. 2003 Mar;89(3):250-5. http://dx.doi.org/10.1067/mpr.2003.38. PMid:12644799.

13. Brosky ME, Major RJ, DeLong R, Hodges JS. Evaluation of dental arch reproduction using threedimensional optical digitization. J Prosthet Dent. 2003 Nov;90(5):434-40. http://dx.doi.org/10.1016/j.prosdent.2003.08.021. PMid:14586306.

14. Patil PS, Chowdhary R, Mishra S. Comparison of custom trays and stock trays using polyvinylsiloxane to evaluate linear dimensional accuracy: an in vitro study. J Indian Prosthodont Soc. 2008;8(3):156-61. http://dx.doi.org/10.4103/0972-4052.49021.

15. Hung SH, Purk JH, Tira DE, Eick JD. Accuracy of one-step versus two-steps putty wash addition silicone technique. J Prosthet Dent. 1992 May;67(5):583-9. http://dx.doi.org/10.1016/0022-3913(92)90151Y. PMid:1527737.

16. Morgano SM, Milot P, Ducharme P, Rose L. Ability of various impression materials to produce duplicate dies from successive impressions. J Prosthet Dent. 1995 Apr;73(4):333-40. http://dx.doi.org/10.1016/S0022-3913(05)80327-0. PMid:7783010.

17. Nissan J, Laufer BZ, Brosh T, Assif D. Accuracy of three polyvinyl siloxane putty-wash impression techniques. J Prosthet Dent. 2000 Feb;83(2):161-5. http://dx.doi.org/10.1016/S00223913(00)80007-4. PMid:10668027.

18. Stober T, Johnson GH, Schmitter M. Accuracy of the newly formulated vinyl siloxanether elastomeric impression material. J Prosthet Dent. 2010 Apr;103(4):228-39. http://dx.doi.org/10.1016/S00223913(10)60035-2. PMid:20362766.

19. Kahn RL, Donovan TE, Chee WW. Interaction of gloves and rubber dam with poly (vinyl siloxane) impression material: a screening test. Int J Prosthodont. 1989 Jul-Aug;2(4):342-6. PMid:2638846.

20. Silva SC, Messias AM, Abi-Rached FO, Souza RF, Reis JM. Accuracy of gypsum casts after different impression techniques and double pouring. PLoS One. 2016 Oct 13;11(10):1-10. http://dx.doi.org/10.1371/journal.pone.0164825.

21. Brosky ME, Pesun IJ, Lowder PD, Delong R, Hodges JS. Laser digitization of casts to determine the effect of tray selection and cast formation technique on accuracy. J Prosthet Dent. 2002 Feb;87(2):204-9. http://dx.doi.org/10.1067/mpr.2002.121240. PMid:11854678. 
22. Garrofé AB, Ferrari BA, Picca M, Kaplan AE. Linear dimensional stability of elastomeric impression materials over time. Acta Odontol Latinoam. 2011;24(3):289-94. PMid:22550824.

23. Basapogu S, Pilla A, Pathipaka S. Dimensional accuracy of hydrophilic and hydrophobic VPS impression materials using different impression techniques - an invitro study. J Clin Diagn Res. 2016 Feb;10(2):ZC56-9. http://dx.doi.org/10.7860/JCDR/2016/17323.7259. PMid:27042587.

24. Rajapur A, Dixit S, Hoshing C, Raikar SP. The influence of tray space and repeat pours on the accuracy of monophasic polyvinylsiloxane impression. J Contemp Dent Pract. 2012 Nov;13(6):824-9. http://dx.doi.org/10.5005/jp-journals-10024-1236. PMid:23404010.

25. Thongthammachat S, Moore BK, Barco MT 2nd, Hovijitra S, Brown DT, Andres CJ. Dimensional Accuracy of Dental Casts: Influence of Tray Material, Impression Material, and Time. J Prosthodont. 2002 Jun;11(2):98-108. http://dx.doi.org/10.1053/jopr.2002.125192. PMid:12087547.

\section{CONFLICTS OF INTERESTS}

The authors declare no conflicts of interest.

\section{*CORRESPONDING AUTHOR}

José Maurício dos Santos Nunes Reis, UNESP - Universidade Estadual Paulista, Faculdade de Odontologia de Araraquara, Departamento de Materiais Odontológicos e Prótese, Rua Humaitá, 1680, 14801-903 Araraquara - SP, Brasil, e-mail: jm.reis@unesp.br

Received: June 23, 2019

Accepted: August 5, 2019 